\title{
СУЧАСНІ ВІДНОСИНИ УКРАЇНА - КНР: ПРОБЛЕМИ І ПЕРСПЕКТИВИ
}

Актуальність теми пов'язана зі зростаючою роллю Китаю як впливового глобального гравця на світовій арені, необхідністю пошуку альтернативних векторів зовнішньої політики України та збільшення динаміки і покращення українсько-китайських відносин, які в 2011 р. набули статусу стратегічних. Китай - лідер серед країн АТР, який стабільно входить до першої десятки торгівельних партнерів України. Відповідно для модернізації України дуже необхідні потужності провідних центрів світу, одним з яких є КНР. У статті проаналізовано основні етапи становлення українсько-китайських відносин, особливості їх розвитку на сучасному етапі та окреслено подальші перспективи взаємин між Україною і КНР. Китай концентрує сили лише на пріоритетних напрямах світової політики. Звідси, подальший розвиток українсько-китайських відносин зростатиме головним чином у сфері економіки, інвестицій, сільського господарства та валютно-фінансових обмінів.

Ключові слова: Україна, Китай, українсько-китайські відносини.

Troyan Serhii, Doctor of Historical Sciences, Professor, National Aviation University, Kyiv, Ukraine

\section{Current Ukraine - China relations: problems and perspectives}

The main objective of this article is to assess the growing importance of China at the global stage. The need for finding alternative ways in foreign policy of Ukraine, increasing and improving of Ukrainian-Chinese cooperation that acquired the status of a strategic in 2011 was emphasizes. It draws our attention to the fact that China is the leader of the Pacific Rim and it is always among 10 Ukrainian Trade Partners. The growing importance of China at the global stage is reflected in its powerful leading role in developing and modernization of Ukraine. The main steps and features of Ukrainian-Chinese cooperation and relationship, new future possibilities to the development of all-round relations between the two countries have been analyzed. China puts greater attention only on priorities ways of the world policy. That's why the further development of Ukrainian-Chinese cooperation will have an impact mainly on economy, investment, agriculture, monetary and financial exchange.

Key words: Ukraine, China, Ukrainian-Chinese relationship.

Троян Сергей Станиславович, доктор исторических наук, профессор, Национальный авиационный университет, Киев, Украина

\section{Современные отношения Украины - КНР: проблемы и перспективы}

Актуальность темы связана с растущей ролью Китая в качестве влиятельного глобального игрока на мировой арене, необходимостью поиска альтернативных векторов внешней политики Украины и увеличение динамики и улучшения украинско-китайских отношений, которые в 2011 г. получили статус стратегических. Китай - лидер среди стран АТР, стабильно входит в первую десятку торговых партнеров Украины. Соответственно для модернизации Украины очень необходимыми являются мощности ведущих центров мира, одним из которых является КНР. В статье проанализированы основные этапы становления украинско-китайских отношений, особенности их развития на современном этапе и намечены дальнейшие перспективы отношений между Украиной и КНР. Китай концентрирует силы только на приоритетних направлениях мировой политики. Отсюда, дальнейшее развитие украинско-китайских отношений будет 
развиваться главным образом в сфере экономики, инвестиций, сельского хозяйства и валютнофинансовых обменов.

Ключевые слова: Украина, Китай, украинско-китайские отношения.

Вступ. Рубіж 1980-х-поч. 1990-х рр. став переломним у процесі формування сучасних китайських зовнішньополітичних концепцій. У Китаї був узятий курс на «мирне піднесення»на основі спільного розвитку з іншими державами. 3'явився інтерес в тому, щоб забезпечити кілька десятиліть роботи в мирній обстановці, а також гарантувати не втягнення Китаю у міжнародні конфлікти. Після закінчення «холодної війни» з'явилося усвідомлення того, що ні військові альянси, ні політична система більше не є запорукою миру і безпеки [17, с. 32]. Концепція нової безпеки КНР, як заявив китайський лідер Цзян Цземінь у виступі на XVI з'їзді Компартії Китаю в листопаді 2002 р., будується на основі взаємної довіри, взаємної вигоди, рівноправності і координації дій між країнами [15]. Цю концепцію можна назвати керівним принципом національної стратегії і найважливішим компонентом сучасної зовнішньої політики Китаю. У ній проглядається тенденція до подальшого зменшення ролі та впливу традиційних принципів «великої держави, що розвивається» і посилення глобальних елементів «великої держави». Офіційний Пекін прагне консолідувати дружні відносини з сусідніми країнами і найкращим чином використовувати наявні нині стратегічні можливості. Невід'ємним принципом китайської дипломатії $є$ дружба щодо сусідів, а щирість - це спосіб придбати більше друзів і партнерів.

3 огляду на це актуальність теми пов'язана зі зростаючою роллю Китаю, як впливового глобального гравця на світовій арені, необхідністю пошуку альтернативних векторів зовнішньої політики України та збільшення динаміки і покращення українсько-китайських відносин, які у 2011 р. набули статусу стратегічних. Китай - лідер серед країн АТР, який стабільно входить до першої десятки торгівельних партнерів України [7, с. 30]. Відповідно для модернізації України дуже необхідні потужності провідних центрів світу, одним з яких є КНР [3, с. 10].

Мета дослідження полягає у здійсненні аналізу основних етапів становлення українськокитайських відносин, особливостей їх розвитку на сучасному етапі та окресленні подальших перспектив відносин між Україною і КНР.

Аналіз попередніх досліджень та публікацій. Договірно-правова база двосторонніх відносин нараховує майже 300 документів. Головними 3 тих, що регулюють політичні відносини між Україною та КНР, є Спільне комюніке про встановлення дипломатичних відносин між Україною та КНР (04.01.1992р.), Спільні українсько-китайські комюніке (31.10.1992 та 24.06.1995 рр.), Спільна (Київська) Декларація між Україною та КНР (06.09.1994р.), Спільна (Пекінська) Декларація про розвиток і поглиблення відносин дружби і співробітництва між Україною та КНР (04.12.1995 р.), Спільна (Київська) Декларація про зміцнення дружби і всебічного співробітництва в XXI столітті (21.07.2001р.), Спільна (Пекінська) декларація України та КНР (18.11.2002р.), Спільна заява України та КНР щодо всебічного підвищення українсько-китайських відносин дружби та співробітництва (02.09.2010р.), Основні напрями розвитку відносин між Україною та КНР на 2010-2012 pp. (02.09.2010р.), Спільна декларація про встановлення та розвиток відносин стратегічного партнерства між Україною та КНР (20.06.2011р.), а також Договір про дружбу і співробітництво між Україною і КНР, Спільна декларація України і Китайської Народної Республіки про подальше поглиблення відносин стратегічного партнерства та Програма розвитку відносин стратегічного партнерства між Україною та КНР на 2014-2018 pp. (усі - 05.12.2013 р.) [1]. Ключовим двостороннім документом у контексті виведення українсько-китайського співробітництва на якісно новий рівень стала Спільна декларація про встановлення та розвиток відносин стратегічного партнерства між Україною та КНР. Раніше, Угодою між Урядом України та Урядом КНР створено Комісію зі співробітництва, яка стала основним механізмом реалізації такого партнерства. Нині українсько-китайські відносини стратегічного партнерства здійснюються на основі Спільної декларації про їх поглиблення i Програми розвитку на 2014-2018 рр. 
Становлення, еволюція, досягнення i проблеми українсько-китайських відносин. Китай визнав незалежність України 27 грудня 1991 р. Дипломатичні відносини між двома країнами було встановлено 4 січня 1992 р. У березні 1993 р. було відкрито Посольство України в КНР. Генеральне консульство України в Шанхаї функціонує з серпня 2001 р. Консульський округ установи охоплює провінції Аньхой, Фуцзянь, Цзянсі, Цзянсу, Чжецзян та м. Шанхай. Посольство КНР у Києві було відкрито в 1992 р. Із 2006 р. в м. Одеса функціонує Генеральне консульство КНР. Консульський округ установи включає територію Автономної Республіки Крим, Донецької, Запорізької, Кіровоградської, Миколаївської, Одеської, Херсонської областей, а також м. Севастополь [7].

У жовтні 1992 р. відбувся державний візит першого Президента України Л. Кравчука до КНР, що започаткував низку візитів найвищих керівників обох країн і заклав підвалини двосторонньої договірно-правової бази. У вересні 1994 р. відбувся офіційний візит в Україну Голови КНР Цзян Цземіня. У грудні 1995 р. - державний візит в КНР Президента України Л. Кучми. Таким чином було остаточно закріплено високий рівень безпосередніх стосунків між керівниками обох держав. Відбувалися активні контакти між всіма гілками влади України та Китаю. У квітні 1993 р. відбувся візит до КНР Голови Верховної Ради України І. Плюща, у квітні 1994 р. - віце-прем’єр-міністра В. Шмарова. У червні 1995 р. Україну відвідав тодішній Прем’єр Держради КНР Лі Пен, у березні 1996 р. - Голова Постійного комітету Всекитайських Зборів Народних Представників Цяо Ши. У грудні 1997 р. відбувся візит до Китаю прем'єр-міністра України В. Пустовойтенка. Започаткована традиція підтримувалася і надалі. Про це свідчить візит Заступника Прем’єра Держради КНР У Ї в Україну в березні 1999 р., Заступника Голови Народної політичної консультативної ради Китаю Чень Цзюньшена в Україну в липні 1999 р., заступника Голови Верховної Ради України С. Гавриша до КНР у квітні 2000 р., Голови КНР Цзян Цземіня у липні 2001 р. [9, с. 33]. У 2002 р. відбувся державний візит Л. Кучми до Китаю, а в 2003 р. офіційний візит Президента України до Гонконгу [5].

Надалі, з вини української сторони виникла пауза, що не сприяла розвитку двосторонніх відносин. Досить прикрим $є$ те, що Україна фактично не скористалася значними можливостями для просування своїх інтересів, які давала Олімпіада у Пекіні (2008) [5].

У відносинах двох держав прорив відбувся у 2010-2011 pр., коли було відновлено політичні контакти на найвищому рівні та оформлено стратегічне партнерство. Початок певного пожвавлення політичного діалогу можна назвати зустріч лідерів держав у квітні 2010 р. в рамках Вашингтонського саміту щодо питань ядерної безпеки, коли сторони заявили про прагнення активізувати діалог [8, с. 30-31].

Візит Президента України до КНР 2 вересня 2010 р. став історичним [3, с. 10]. Відновлення діалогу на найвищому рівні було найважливішою передумовою успішного співробітництва України i Китаю у торгово-економічній, науково-технічній і гуманітарній галузях. Пряме, безпосереднє спілкування Президента України з лідером Китаю мало величезне значення для встановлення нового рівня взаємної довіри між представниками управлінського апарату та бізнесових кіл наших країн [5]. У ході візиту було підписано 13 двосторонніх документів, які передбачали надання Україні інвестиції у розмірі 4 млрд. доларів США. Один із найважливіших документів - «Основні напрями українсько-китайських відносин (Дорожня карта) на 2010-2012 роки» $[9$, с. 6]. Сторони продемонстрували готовність вжити дієвих заходів для наповнення двосторонніх відносин стратегічним змістом і максимально ефективно використати наявний потенціал українсько-китайського співробітництва [3, с. 11].

Ще однією важливою подією, яку також було названо історичною, став державний візит у червні 2011 р. Голови КНР Ху Цзіньтао до України. Найважливішим результатом, ключовим підсумком перебування його стало підписання Спільної декларації про встановлення та розвиток відносин стратегічного партнерства між Україною та КНР. У документі фіксується започаткування відносин стратегічного партнерства між країнами, а також визначаються принципи, на яких ці взаємини базуються. Йдеться, зокрема, про взаємну підтримку державного суверенітету та 
територіальної цілісності, повагу шляху розвитку кожної з держав, взаємне незастосування сили або загрози силою, економічного чи іншого тиску [13, с. 59].

Важливо підкреслити, що у рамках візиту під час переговорів у Києві у вузькому колі та у складі делегацій висловлювалася думка щодо розширення прагматичного змісту двосторонніх відносин [13, с. 59]. Китай є одним із найважливіших стратегічних партнерів для України і посідає друге місце за обсягом товарообігу. Україна виступає за посилення торговельно-економічних зв'язків із Китаєм і поглиблення науково-технічної співпраці в освоєнні космосу, розвитку авіапрому, реалізації спільних інфраструктурних проектів. За підсумками 2015 р. обсяг товарообігу України з КНР становив 7,074 млрд. дол. США, з яких на експорт українських товарів у Китай припало 3,557 млрд. дол. США. У січні-червні 2016 р. товарообіг між Україною та КНР склав 3,525 млрд. дол. США, що більше аналогічного показника січня-червня 2015 р. на 1,0 \% [7].

Під час останнього державного візиту в КНР Президента України (грудень 2013 р.) було укладено Договір про дружбу і співробітництво між Україною і КНР та Спільну декларацію України i КНР про подальше поглиблення відносин стратегічного партнерства, а також затверджено Програму розвитку відносин стратегічного партнерства між Україною та КНР на 2014-2018 pp.

У січні 2015 р. відбулася зустріч Президента України П. Порошенка 3 прем'єром Державної Ради КНР Лі Кецяном у рамках Всесвітнього економічного форуму (м. Давос). У жовтні 2014 р. на полях Саміту АССМ у Мілані міністр закордонних справ України П. Клімкін провів зустріч з міністром закордонних справ КНР Ван Ї.

Сторони підтримують доволі активні міжпарламентські зв'язки. У нинішньому складі Верховної Ради України функціонує група 3 міжпарламентських зв'язків 3 КНР на чолі 3 депутатом А. Павелком. У Всекитайських зборах народних представників працює група дружби 3 Україною на чолі 3 Головою Комітету у закордонних справах Фу Їн. У рамках міжпарламентських контактів у червні 2015 р. був здійснений візит до КНР групи народних депутатів України на чолі з Ю. Луценком.

Основним механізмом розбудови співпраці у культурно-гуманітарній сфері $є$ Підкомісія 3 питань співробітництва у сфері культури міжурядової Комісії зі співробітництва. У рамках другого засідання Підкомісії (вересень 2013 р.) сторонами укладено Програму культурного співробітництва між Міністерством культури України та Міністерством культури Китайської Народної Республіки на 2013-2017 pp.

Серед проектів, що реалізуються або плануються до реалізації в Україні за рахунок китайських експортних кредитів, виокремимо такі:

1. Виконання контракту щодо реалізації національного проекту «Повітряний експрес» організація залізничного пасажирського сполучення м. Київ - міжнародний аеропорт «Бориспіль» та будівництво ін. інфраструктурних об'єктів Київського регіону» (вартість проекту - 372 млн. доларів США).

2. Реалізація спільних проектів у рамках підписаного Меморандуму про взаєморозуміння між Міністерством аграрної політики та продовольства України і Експортно-імпортним банком КНР щодо співпраці у галузі сільського господарства на суму 3 млрд. дол. США.

3. Реалізація спільних проектів у галузі енергетики у відповідності до Кредитної угоди між НАК «Нафтогаз України» і Банком розвитку Китаю на суму 3,65 млрд. дол. США. Зокрема, передбачені будівництво установки газифікації вугілля на Одеському припортовому заводі, модернізація низки українських ТЕЦ, будівництво газового інтерконнектора між Україною та Польщею, модернізація Шебелинського ГПЗ ПАТ «Укргазвидобування».

4. Здійснення пілотного проекту будівництва соціального житла 3 іпотечним кредитуванням в м. Київ вартістю 1 млрд. дол. США в рамках Меморандуму про взаєморозуміння щодо співпраці 3 питань будівництва доступного житла в Україні між Міністерством регіонального розвитку, будівництва та ЖКГ та Китайською державною компанією «СІТІС Construction Co., Ltd.». 
5. Виконання третьої п’ятирічної Програми співробітництва в космічній галузі (на 20112015 рр.), а також розробка четвертої (на 2016-2020рр.).

Перспективним стратегічним напрямом економічного співробітництва 3 KHР $\epsilon$ безпосереднє залучення України до реалізації ініціативи Голови КНР щодо розбудови Економічного поясу Шовкового шляху. Зокрема, Китай запропонував Україні створити зону вільної торгівлі. Про це заявив посол КНР Ду Вей на Першому міжнародному українському форумі Шовкового шляху 2016 Ukraine Silk Road Forum, який відбувся в Києві 7 листопада 2016 р.

Висновки. Володіючи глобальним спектром зовнішньополітичних інтересів, але обмеженими зовнішньополітичними ресурсами, Китай концентрує сили лише на пріоритетних напрямах світової політики. Звідси, подальший розвиток українсько-китайських відносин зростатиме головним чином у сфері економіки, інвестицій, сільського господарства та валютнофінансових обмінів.

Надалі зовнішньоторговельні контракти України 3 Китаєм можуть бути переведені 3 доларів у юані. Оскільки Україна $є$ прямим імпортером китайських товарів, перехід зовнішньоторговельних контрактів у національні валюти допоможе знизити попит на долар на українському валютному ринку.

Співпраця у сфері кредитування (особливо це стосується кредитування агропромислового та енергетичного комплексів) під відносно нижчі відсотки сприятиме розвитку суб'єктів кредитування та диверсифікації кредитних надходжень.

Враховуючи виключний прагматичний курс зовнішньої політики Китаю, відносини між Україною та КНР зберігатимуть тенденцію до сталого розвитку, проте не зможуть у найближчій перспективі реалізуватися у повній мірі як стратегічні.

\section{Список використаних джерел:}

1. Договірно-правова база між Україною та Китаєм [Електронний ресурс] // Посольство України в Китайській Народній Республіці та в Монголії (за сумісництвом). - Режим доступу: http://china.mfa.gov.ua/ua/ukraine-cn/legal-acts. - Назва з екрану. - Дата звернення 23.01.2017.

2. Коваль О. Пекін розставив пріоритети [Електронний ресурс] / О. Коваль // Дзеркало тижня. - 2010. - № 23. - Режим доступу: http://dt.ua/articles/83377. - Назва 3 екрану. - Дата звернення 15.01.2017.

3. Костенко Ю. Український прорив на азіатському напрямку / Ю. Костенко // Зовнішні справи: наук. журн. - 2010. - № 9/10. - С. 10-12

4. Крамар О. Україна як сировинна колонія [Електронний ресурс]: Янукович робить державу залежною від Китаю / О. Крамар // Тиждень.uа. - Режим доступу: http://tyzhden.ua/Economics/58379. - Назва з екрану. - Дата звернення 15.01.2017.

5. Литвин I. Українсько-китайські відносини [Електронний ресурс]: від стагнації до $\begin{array}{lllll}\text { прориву } & \text { I Л Литвин. } & - & \text { Режим доступу: }\end{array}$ http://www.aucc.org.ua/ukrajinsko_kitajske_spivrobitnictvo_vid_stagnaciji_do_prorivu_art_558.htm. - Назва з екрану. - Дата звернення 13.02.2017.

6. НБУ і Народний банк Китаю підписали угоду про свопи на 2,36 мільярда доларів [Електронний ресурс] // Економічна правда. - Режим доступу: http://www.epravda.com.ua/news/2012/06/26/327728/. - Назва 3 екрану. - Дата звернення 15.02.2017.

7. Політичні відносини і торговельно-економічне співробітництво між Україною та Китаєм між Україною та Китаєм [Електронний ресурс] // Посольство України в Китайській Народній Республіці та в Монголії (за сумісництвом). - Режим доступу: http://china.mfa.gov.ua/ua/ukrainecn/diplomacy. - Назва з екрану. - Дата звернення 20.02.2017.

8. Розвитку українсько-китайських відносин - більш грунтовний підхід / Інф. «3. С.» // Зовнішні справи: наук. журн. - 2010. - № 2. - С 30-32. 
9. Седнєв В. В. Українсько-китайські відносини: надбання, перспективи [Електронний ресурс] / В. В. Седнєв // Украина-Китай. - 2002. - № 1 (5). - С. 33-37. - Режим доступу: http://www.sinologist.com.ua/ukr/Sednev.html. - Назва з екрану. - Дата звернення 23.02.2017.

10. Семенов В. Складові китайського прориву: (до підсумків офіційного візиту Президента України до КНР) / В. Семенов // Зовнішні справи: наук. журн. - 2010. - № 3/4. - С. 6-9.

11. Сидоренко С. Зустрілися два товариші [Електронний ресурс]: Україна і Китай домовилися про стратегічну співпрацю / С. Сидоренко, О. Габуєв. - Режим доступу: http://www.aucc.org.ua/Zustrichalisja_dvatovarishi_Ukrajina_i_Kitaj_domovilisja_pro_strategichnu_spi vpracju_art_790.htm. - Назва з екрану. - Дата звернення 23.01.2017.

12. Україна залучила 85 млн. доларів китайських інвестицій у вугільну галузь [Електронний ресурс] // Урядовий портал. - Режим доступу: http: //www.kmu.gov.ua/control/uk/publish/article?art_id=244977815\&cat_id=244276429. - Назва 3 екрану. - Дата звернення 23.01.2017.

13. Українсько-китайський прорив / Інф. Посольства України у КНР // Зовнішні справи: наук. журн. - 2011. - № 7/8. - С. 59-60.

14. Харламов П. Житница Китая [Электронный ресурс] / П. Харламов // Эксперт. - Режим доступа: http://www.expert.ua/articles/23/0/10450/. - Назва 3 екрану. - Дата звернення 13.02.2017.

15. Цзэминь Цзян. Доклад на XVI Всекитайском съезде Коммунистической партии Китая 8 ноября 2002 года / Цзэминь Цзян. - Пекин: Жэньминь чубаньшэ, 2002. - 56 с.

16. Вэньвэй Ч. Шанхайская организация сотрудничества: достижения, возможности, вызовы / Вэньвэй Чжан. - Пекин: Бэйцзин чубаньшэ, 2004. - 78 с.

17. Haass Richard N. Bringing China into the fold / Haass Richard N. // Newsweek. - Dec. 2008Jan. 2009. - pp. 14-15.

\section{References:}

1. Embassy of Ukraine in the People's Republic of China and in Mongolia. Legal basis of Ukraine and China. [online] Available at: http://china.mfa.gov.ua/ua/ukraine-cn/legal-acts. [Accessed 23 January 2017]. Title drom the screen.

2. Koval, O. (2010). Beijing has prioritized. Dzerkalo tyzhnia [Mirror of the week], [online] no. 23. Available at: http://dt.ua/articles/83377. [Accessed 15 January 2017]. Title drom the screen.

3. Kostenko, Yu. (2010). Ukrainian breakthrough in the Asian direction. Zovnishni spravy: naukovyi zhurnal [External affairs: a scientific journal], no. 9-10, pp. 10-12.

4. Kramar, O. (2011). Ukraine as a raw material colony: Yanukovych makes the country dependent on China. Tyzhden.ua. [Week.ua]. [online] Available at: http://tyzhden.ua/Economics/58379. [Accessed 15 January 2017]. Title drom the screen.

5. Lytvyn, I. (2011). Ukrainian-Chinese relations: from stagnation to breakthrough. [online] Available at: http://www.aucc.org.ua/ukrajinsko_kitajske_spivrobitnictvo_vid_stagnaciji_do_prorivu_art_558.htm. [Accessed 13 February 2017]. Title drom the screen.

6. The NBU and the People's Bank of China signed a swap agreement worth $\$ 2.36$ billion. Ekonomichna pravda [Economic truth], [online] Available at: http://www.epravda.com.ua/news/2012/06/26/327728/. [Accessed 15 February 2017]. Title drom the screen.

7. Embassy of Ukraine in the People's Republic of China and in Mongolia. Political relations and trade and economic cooperation between Ukraine and China between Ukraine and China. [online] Available at: http://china.mfa.gov.ua/ua/ukraine-cn/diplomacy. [Accessed 20 February 2017]. Title drom the screen.

8. The development of Ukrainian-Chinese relations is a more thorough approach. (2010). Zovnishni spravy: naukovyi zhurnal [External affairs: a scientific journal], no. 2, pp. 30-32. 
9. Sedniev, V.V. (2002). Ukrainian-Chinese relations: achievements, prospects. Ukrayna-Kytai [Ukraine-China], [online] no. 1(5), pp. 33-37. Available at: http://www.sinologist.com.ua/ukr/Sednev.html. [Accessed 23 February 2017]. Title drom the screen.

10. Semenov, V. (2010). The components of the Chinese breakthrough: (to the outcome of the official visit of the President of Ukraine to the PRC). Zovnishni spravy: naukovyi zhurnal [External affairs: a scientific journal], no 3-4, pp. 6-9.

11. Sydorenko, S., Habuiev, O. Two comrades met: Ukraine and China have agreed on strategic cooperation. [online] Available at: http://www.aucc.org.ua/Zustrichalisja_dvatovarishi_Ukrajina_i_Kitaj_domovilisja_pro_strategichnu_spi vpracju_art_790.htm. [Accessed 23 January 2017]. Title drom the screen.

12. Government portal. Ukraine has attracted \$85 million in Chinese investments in the coal industry [online] Availiable at: http: //www.kmu.gov.ua/control/uk/publish/article?art_id=244977815\&cat_id=244276429. [Accessed 13 February 2017]. Title drom the screen.

13. Embassy of Ukraine to the People's Republic of China. (2011). Ukrainian-Chinese breakthrough. Zovnishni spravy: naukovyi zhurnal [External affairs: a scientific journal], no 7-8, pp. 5960.

14. Kharlamov, P. (2012). Chinatan of China. Ekspert [Expert] [online] Available at: http://www.expert.ua/articles/23/0/10450/. [Accessed 23 January 2017]. Title drom the screen.

15. Zemin, J. (2002). Report at the XVIth All-Chinese Congress of the Chinese Communist Party on November 8, 2002). Beijing: Zhenmin chubanshe, p. 56.

16. Venvei, Ch. (2004). Shanghai Cooperation Organization: achievements, opportunities, challenges. Beijing: Beitczin chubanshe.

17. Haass, R.N. (2008-2009). Bringing China into the fold. Newsweek. pp. 14-15.

(C) Троян С. С., 2018 